\title{
DIAGNOSTIC AND THERAPUTIC CHALLENGE IN LIPOMATA AROUND SHOULDER GIRDLE
}

By

EISSA ABDEL HAMED IBRAHIM ${ }^{1}$ and YASSER AHMED EL SAYED ${ }^{2}$

Consultant of General Surgery ${ }^{1}$ and Consultant of Thoracic Surgery ${ }^{2}$, Military Medical Academy, Cairo, 11291, Egypt (Correspondences: eissa.abdelhameed@gmail.com; Eissa-1961@yahoo.com and yasser.elsaid31@yahoo.com)

\section{Abstract}

Lipoma is slow growing tumors and often occurs under the skin on the neck, shoulders, arms, back, abdomen and thighs. However, occasionally lipoma may be present in deep location or originate within muscle.

Lipoma affected only $1 \%$ of population, and commonly found in adults and is higher in man than in women. The most common benign mesenchymal tumors composed of fat cell of adult type, diffused or encapsulated type. Surgical removal is indicated when causing trouble as site, size, appearance and presence of pain. The study was carried on 35 male patients presented by lipoma around shoulder girdle operated in Kobry El-Kobba Military Medical Campus.

The patients were divided into four groups, G1:25 patients with primary subcutaneous lipoma, G2: 8 patient with subscapular lipoma, G3: 1 patient with giant submascular left shoulder lipoma, and G4: 1 patient with giant subscapular lipoma "diagnosed before operation" including complete surgical excision was done under general anesthesia in all the patients without any recurrence.

Keywords: Lipoma, Shoulder girdle, Shoulder joint movement

\section{Introduction}

Involvement of adipose-derived stem/ progenitor/stromal cells (ASCs) in lipomas development was suggested, but the pathogenesis and pathophysiology of this tumor remain unclear. Lipoma is a slowly growing tumor composed of fat cell of adult type with positive balance of adipocyte turnover caused proliferating ASCs and several transcriptional differences from adipose tissue enlargement in obesity (Suga et al, 2009).

Lipomatous soft-tissue tumors are the commonest neoplasms encountered by physicians. They range from benign lipomas to high-grade liposarcomas. Unplanned excisions of sarcomas were commonly due to the presumptive diagnosis of lipoma and can be avoided by understanding diagnostic magnetic resonance imaging appearance. The large deep lipomatous masses and liposarcomas should be sent to a sarcoma referral center for definitive treatment. Lipomas are often occurring under the skin of the shoulders, arm, thighs, abdomen, back, and neck (Johnson et al, 2018), commonly found in adult men than in women (Luba et al, 2003). Liposarcomas were classified into five histo- logic subtypes: well-differentiated, dedifferentiated, myxoid round cell, and pleomorphic that differed in outcomes and patterns of recurrence. Surgical resection is the mainstay of curative treatment; however, large, high grade liposarcomas may benefit from multimodality treatment with chemotherapy and radiation. A histologic-subtype specific nomogram provides accurate survival predictions. Prospective randomized of the clinical trials continue to improve care of patients with liposarcoma (Dalal et al, 2008). Any suspicious soft-tissue tumor was diagnosed, the combined information gathered from accurate preoperative radiographic planning and X-rays or surgical biopsy was of tremendous value for establishing the most appropriate therapeutic program, highly adapted to histopathological findings (Loubignac et al, 2009).

Genomic pattern of liposarcoma showed copy number alternations, amplification of chr 129 , as a major driver of initiation of malignancy along with several putative driver somatic mutations of P13 KCA, TP53, $\mathrm{NF}_{1}$, and EGFR (Kanojia et al, 2015). Exact cause of lipoma was still not known, but lipo 
mas were identified with genetic rearrangement including structural changes at $12 \mathrm{q} 13$ 15, $13 q$ and $6 p$ 21-23 regions (Nishio, 2011). Lipoma appears to be close to well differentiated liposarcoma as in terms of their HMGA2 structural alternations and high adipogencity (Hatano et al, 2004), without convincing literature existed to show liposarcomas arises from lipomas (Kanojia et al, 2019).

This study aimed to present clinical diagnosis and surgical intervention with lipomata around shoulder girdle among Egyptian patients in Kobry El-Kobba Military Medical Campus.

\section{Materials and Methods}

The study included 35 male \& female patients, with swelling around shoulder girdle. A medical sheet was filled out on each patient. The commonest complaint was a lump with unsightly or interfered with movement, especially if it was pedunculated. Hard and painful lump, detailed clinical features associated with these begin tumors presented in supplementary (Tab. 1).

Table 1: Patients presented by one or more of sign and symptoms

\begin{tabular}{|c|c|}
\hline Symptoms and signs & Number of patient / ages \\
\hline Duration & $\begin{array}{l}3 \text { month, } 1 \text { patient, } 21 \text { years, giant subscapular lump. } 5 \text { years, } 1 \text { patient, Giant shoulder lump. } 2-3 \\
\text { years } 25 \text { patients small }(5-10 \mathrm{~cm}) \text { and } 3-4 \text { years, } 8 \text { patients, " } 10-15 \mathrm{~cm} \text { " subscapular lump }\end{array}$ \\
\hline Lump & $\begin{array}{l}1 \text { patient unsightly lump "cap on shoulder", } 1 \text { patient giant subscapular lump, } 8 \text { patient small sub- } \\
\text { scapular lump, \& } 25 \text { subcutaneous lump }\end{array}$ \\
\hline Painful lump & 2 patients, 33 patients no pain \\
\hline Hard lump & 1 patients, 34 patients of lump \\
\hline Multiplicity & No-all patients presented by single lump \\
\hline Pedunculation & No \\
\hline Interfering with joint movement & 2 patient \\
\hline $\begin{array}{l}\text { Skin over lump: A- Ulceration } \\
\text { B- Color } \\
\text { C- Temperature }\end{array}$ & $\begin{array}{l}\text { No } \\
\text { Normal coloration } 2 \text { patients with little stretched and glazed color-visible paint blue streaks in one } \\
\text { Temperature of overlying skin is normal to all patients }\end{array}$ \\
\hline Tenderness & Discomfort in 1 patients but palpated firm to soft without discomfort "tendor" in 34 patients \\
\hline $\begin{array}{l}\text { Felling something go away under } \\
\text { scapula }\end{array}$ & 8 patients \\
\hline $\begin{array}{l}\text { Shape: A- Spherical } \\
\text { B- Flattened } \\
\text { C- Discoid (hemi-spherical) } \\
\text { D- Cap- on shoulder }\end{array}$ & $\begin{array}{l}25 \text { patients - subcutaneous lump } \\
8 \text { patient's subscapular lump } \\
1 \text { patient "giant subscapular lump" } \\
1 \text { patients "Giant shoulder lump" }\end{array}$ \\
\hline Size & 2 patients $15-20 \mathrm{~cm}, 8$ patients $10-15 \mathrm{~cm} \mathrm{\&} 25$ patients $5-10 \mathrm{~cm}$ \\
\hline Surface & Smooth and lobulated \\
\hline Edge & $\begin{array}{l}\text { Soft, compressible slips away "slip sign" in } 33 \text { patients, Lobules seen and felt on surface and at } \\
\text { lump edge in one patient and Fluctuation feel in one patient }\end{array}$ \\
\hline Lymphatic drainage & Regional lymph node not be enlarged in all patients \\
\hline
\end{tabular}

All patients aged between 22 to50 years and divided into four groups: G1:25 patients with primary subcutaneous lump, G2:8 patients with subscapular lump, G3:1 patient with giant left should lump, \& G4:1 patient with giant subscapular lump

Laboratory examination: All were subjected to chemical investigations, coagulation profile and INR, renal and liver profile, blood sugar, CBC and ECG.

Imaging: X-ray, CT up on lump and $\mathrm{x}$ ray chest for operation.

Diagnosis was by the clinical examination (Tab. 1) and imaging "U.S, CT, MRI and Xray" operation was done after obtaining informed written consent from patients, surgical excision was done under-general endo- tracheal anesthesia, insertions of drain and the specimen was examined histopathology. Outcome of operation as hospital stay, infection rate, operative time, bleeding cosmetic appearance, type of patients, and histopathological examination.

In the primary single subcutaneous lipoma; twenty five male and female patients aged 18-45 year's "main age 30 years" 7civilian and 18 military, with swelling around shoulder since 2 years, $8 \mathrm{~cm} \mathrm{x} 7 \mathrm{~cm}$, and seeking medical advice, the swelling gradually increase in size, not preceded by trauma, soft mobile, lobulated at edge and surface, it slips away from the examining finger, "slip sign" skin over it showing multiple dimple during move, normal skin colure, tempera- 
ture and no tender over it. The patients informed by diagnosis and patients prepared for operation after obtaining informed written consent from patient, general investigation done and US.

Operation: General endotracheal anesthesia, marking swelling and skin incision (Fig. 1). Sterilization operative site and draping it, skin incision done at "Langer line" site of marking, dissection of swelling from surround structure, hemostasis, insertion of suction drain, closure of wound and skin by interrupted simple structure (Fig. 2), Removed swelling $5 \mathrm{~cm} \times 7 \mathrm{~cm}$ examined macroscopically and histopathological examination (Fig. 3).

Postoperative: Antibiotic, analgesic, patients were discharged next postoperative day, drain was removed on 3-4 postoperative day and suture on $7^{\text {th }}$ postoperative day and followed up in the outpatient clinic.

In the subscapular lipoma; eight male and female military patients aged 18-30 years, with main of 22 years. The patients seek medical advice because they felt swelling underneath scapula by examination: examination of them were done when muscle relaxed and muscle contracted "contraction of muscle done by push arm agents resistant" swelling appeared at medical inferior aspect of scapula, soft, lobulated, slip sign normal skin colure, temperature but no tender over it. The diagnosis, patients were prepared for operation after obtaining the informed written consent from all of them according to the ethical rules.

Operation: General endotracheal anesthesia, patients in prone position marking skin incision as in group IV i.e. At medical border of scapula after sterilization operative site and draping patients (Fig. 4), Muscle splitting "latissimus dorsi muscle" dissection of swelling from surround stricture and delver it hemostasis had done, insertion of drain and closure of wound (Fig. 5) Specimen $5 \mathrm{~cm} \times 6 \mathrm{~cm}$ was sent for histopathological examination both macroscopic and microscopic examination were done (Fig. 6).
Postoperative: antibiotic \& analgesia were given and patients were discharged on the second postoperative day, drain was removed on the $3^{\text {rd }}$ postoperative day and suture on the $7^{\text {th }}$ postoperative day and they were follow up at the outpatient clinic.

The patient giant left shoulder lipoma, was civilian male patient, 45 years old presented by painless, soft, gradually increasing, left shoulder swelling, since 8 years. Examination showed firm, soft, palpel lump not tender, lobulated surface and edge without slips sign, deep seated, normal skin and temperature over it and there limitation and pain during shoulder movement.

Investigation: The chemical investigation, ECG and chest X-ray, "CT, US and plain Xray, of left shoulder" CT, showed soft tissue mass, with intact bone and normal shoulder stricture, US, hyperechoic mass without posterior acoustic shade X-ray left shoulder, indentation shaft of left humorous. Patient was informed by diagnosis "giant left shoulder lipoma" and was prepared for operation after obtaining the written consent from him.

Operation: General endotracheal anesthesia, so-pin position, adduction left arm and elevation of left shoulder (Fig. 7), Sterilization of skin by povidone iodine, dripping patient and $\mathrm{Z}$ skin incision over left shoulder (Fig. 8), Muscle splitting "deltoid muscle" vertical splitting, deltoid muscle fiber (Fig. 9). Dissection of swelling from surrounding stricture to be delivered away from the shoulder region showed the swelling site under the muscle fiber (Fig. 10a \& b). Insertion of drain was approximation of deltoid muscle fiber; closure of skin and subcutaneous tissue by interrupted suture-removal excess skin (Fig. 11a \& b). Specimen was sent for histopathological examination after being measured (Fig. 12).

Postoperative: Antibiotic \& analgesic were given. Patient was discharged on $3^{\text {rd }}$ postoperative day and drain was removed on $5^{\text {th }}$ postoperative in outpatient clinic. Physiotherapy was done 2 week after operation.

In the patient with giant left subscapular 
lipoma, 21 years old military male student, presented by swelling under left scapula, since 4 months, gradually increased in size after the violence exercises and the swelling became painful and seeking medical advice.

Examination: soft swelling at medical border, inferior angle of scapula, scapula move over it and patient felling smoothing move under scapula, swelling partially disappear after contraction of muscle and there lobulation over surface and at edge with normal skin and temperature over it. Chemical investigation, chest X-ray and ECG - CT and plain X-ray up on left shoulder, no pathology found (Fig. 13), patient informed by diagnosis and prepared for operation.

Operation: Landmark line of the incision and scapula before operation, superior- infertio and medial border of scapula, line of incision med-way between medial border of scapular and med line (Fig. 14). General endotracheal anesthesia, prone position, abduction left upper limb, sterilization operative, site draping patient and incision done at the marking line (Fig. 15a \& b).

Muscle splitting, dissection of swelling from surrounding structure "from chest wall" dur- ing dissection oily fluid i.e. synovial fluid, come from swelling, complete separation of swelling from chest wall (Fig. 16a \& b). After complete separation of swelling from chest wall, there is an artricular surface at the third rib-covered by articular cartilage and hard mass at ventral aspect of scapula covered by fibrous capsule (Fig. 17a \& b), Excision hard mass from ventral aspect of scapula and curettage of the articular of the third rib (Fig. 18a \& b). Closure of wound in layer was by suturing serratus muscle, latissimus dorsi; insertion of drain and closure of wound (Fig. 19a \& b). Heart mass and fibrous capsule were sent for histopathological examination (Fig. 20).

Postoperative: Antibiotic and analgesic were given and patient was discharged on $5^{\text {th }}$ post-operative day, after removal of drain. The clips were removed on $7^{\text {th }}$ postoperative day, physiotherapy 2 week postoperative and follow up every 2 week up to 6 months.

\section{Results}

The results were shown in tables $(1 \& 2)$ and figures $(1,2,3,4,5,6,7,8,9,10,11$, $12,13,14,15,16,17,18,19 \& 20)$

Table 2: Group of patients:

\begin{tabular}{|c|c|c|c|c|}
\hline Variants & Group 1 & Group 2 & Group 3 & Group4 \\
\hline Patients & 25 & 8 & 1 & 1 \\
\hline Ages & $18-45$ years "main 30 years" & $18-30$ years average 22 & 45 years & 21 years \\
\hline $\begin{array}{l}\text { Civilian } \\
\text { military }\end{array}$ & $\begin{array}{l}\text { 7- civilian } \\
18 \text { - military }\end{array}$ & All military & Civilian & Military \\
\hline Sex & 5 females and 20 males & 2 females \& 6 males & One male & One male \\
\hline $\begin{array}{l}\text { Swell- } \\
\text { ing durat } \\
\text { ion }\end{array}$ & Long duration $>3$ years & Long duration $>4$ years & Long duration $>8$ years & $\begin{array}{l}\text { Short duration } 3 \text { months } \\
\text { after violence exercises }\end{array}$ \\
\hline $\begin{array}{l}\text { Tissue } \\
\text { around it }\end{array}$ & $\begin{array}{l}\text { Pressure atrophy of tissue around } \\
\text { prod-ucing false capsule }\end{array}$ & Normal tissue around it & $\begin{array}{l}\text { Indentation of outer cor- } \\
\text { tex of left humeral bone }\end{array}$ & Normal tissue around it \\
\hline $\begin{array}{l}\text { Hospital } \\
\text { stay }\end{array}$ & 1 day & 3 days "main days" & 3 days & 5 day \\
\hline Infection & $\begin{array}{l}5 \text { patients mild infection treated by } \\
\text { antibiotic and dressing }\end{array}$ & $\begin{array}{l}\text { 4, 3-mild infection treated } \\
\text { by antibiotic. One needed } \\
\text { open wound to drain pus. }\end{array}$ & No infection & No infection \\
\hline $\begin{array}{l}\text { Operative } \\
\text { time }\end{array}$ & $30-40$ minutes & $40-60$ minutes & $1 \frac{1}{2}$ hour & 2 hours \\
\hline Bleeding & No bleeding & No significant bleeding & No bleeding & No bleeding \\
\hline $\begin{array}{l}\text { Cosmetic } \\
\text { results }\end{array}$ & Good & Good & $\begin{array}{l}\text { Patient happy by post- } \\
\text { operative cosmetic results }\end{array}$ & $\begin{array}{l}\text { Patient proud by post- } \\
\text { operative result }\end{array}$ \\
\hline $\begin{array}{l}\text { Histopa- } \\
\text { thologic } \\
\text { examina- } \\
\text { tion }\end{array}$ & $\begin{array}{l}\text { Pur-lipoma } 12 \text { patients nevolipoma } 5 \\
\text { patients } \\
\text { - Fibro-lipoma } 3 \text { patients } \\
\text { - Elasto lipoma } 2 \text { patients }\end{array}$ & $\begin{array}{l}5 \text { patients elasto-lipoma } \\
\text { 3- patients elasto-fibro- } \\
\text { lipoma }\end{array}$ & $\begin{array}{l}\text { Fibro lipoma } \\
\text { No malignancy } \\
800 \mathrm{~g} \text { weight }\end{array}$ & $\begin{array}{l}\text { Osteor chondroma associ- } \\
\text { ated with area of angioma- } \\
\text { tus malformation } \\
\text { No maligence }\end{array}$ \\
\hline $\begin{array}{l}\text { Recur- } \\
\text { rence }\end{array}$ & No evidence of recurrence & No recurrence & No recurrence & No recurrence \\
\hline
\end{tabular}




\section{Discussion}

Primary subcutaneous lipomas are a slowly growing lump composed of a cluster of fat-cells of adult's type. The fat cell become over active and distended with fat, they become palpable lumps. Lipoma may be diffuse or encapsulated. The present study discussed the single encapsulated lipoma but diffuse lipoma, occasionally occurs in subcutaneous tissue of neck, from which it spreads no to the pre-auricular region of the face, the tumor is not obviously encapsulated. The subcutaneous lipomata are most common in the subcutaneous fat of the upper limb, especially the subcutaneous fat of forearm. But, can occur any-where there is fate, the head and neck area, abdominal wall and thighs are particularly favored sites (Bailey and Love, 2000).

Treatment of lipoma if its causing trouble on account of its site, appearance, pain and size, removal was indicated, any projection like-finger into the surrounding tissue found during operation should also be removed the tumor was relatively a vascular, care was needed to obtain complete hemostasis in the resulting cavity otherwise hematoma was common that might be followed by infection and delay in wound healing drainage was often necessary.

High motilities group A2 "(H.M.P.A $\left.A_{2}\right)$ " is a small non-histone chromosomal protein. It has no intrinsic transcriptional activity, but con modulates transcription by altering the chromatin architecture (Hock et al, 2007; Pallante et al, 2015). HMGA 2 over expression has been reported to be associated with tumorigenesis and progression in many human cancers (Zhang et al, 2016). The effect of $H M G A$ gene silencing was shown to be also variable. Proliferation of human retinoblastoma and liposarcoma cells was suppressed by $H M G A 2$ gene silencing (Malek et al, 2008).

In the twenty five male and female military patients swelling, diagnosis clinically simple subcutaneous lipoma and US done to all patients, revealed a hyperechoic mass having no posterior acoustic enhancement operation done under general anesthesia and excised mass examined macroscopically and microscopically to confirm diagnosis macroscopic examination elastic mass surrounded by brown capsule, and microscopic examination revealed 12 patients pure-lipoma, five patients naevolipoma, three patients fibrolipoma \& two patients elasto-fibrolipoma with-out evidence of recurrence or malignant sarcoma.

The eight male and female military patients were admitted at the Kobry-El-Kobba Military Surgical Department. They suffered from palpable mass at the inferior angle of scapulae; all masses were at left scapula and periscapular discomfort, by physical examination. There was mobile, elastic mass located at the left inferior angle of scapula and disappear under subscapular region. X-ray chest and CT showed no suspicious lesion.

Surgical excision was done under general endotracheal anesthesia, posterior thoracic wall incision, and splitting the fiber of latissimus dorsi muscle, there was $7 \mathrm{~cm} \times 9 \mathrm{~cm}$ capsulated mass in the subscapular region.

The mass was excised and examined macroscopically and microscopically, macroscopic examination was given. It was $7 \mathrm{~cm} \mathrm{x} 9 \mathrm{~cm} \mathrm{x}$ $5 \mathrm{~cm}$, elastic "rubbery" mass with a capsulated brown appearance, the cut surface was grayish white and intermixed with yellow, and the yellow area "lipomatous" were located in peripheral part and in central part of the mass.

Microscopic examination was done in histopathological department showed thin fibrous capsule, the mass, consisted of collagenous stroma, fragmented fibers and marked mature adipose tissue, and histopathological diagnosis, 5 patients elasto-lipoma (2 female \& 3 male) and 3 patients elasto fibrolipoma.

Elasto-fibroma was first defined by De-Nictolis et al. (1995) in the anterior mediastinum and by Erkilic et al. (2005) in the subscapular area, described as an encapulsated mass of abnormal elastic fibrous and con- 
nective tissue mixed with mature adipose tissue. No bilateral elasto-fibrolipoma was previously described but, Ünal et al. (2015) reported a well-defined, bilateral subscapular lesion in a thin of elastic fibers, globules, and band of connective tissue mixed with fat tissue

In the civilian male patients 45 years, presented with 8 years, history of painless, gradually increasing soft, left shoulder swelling, with limitation of movement especially abduction movement and unsightly "ugly" appearance. So, the indication of operation was limitation of movement and ugly appearance. Under general endotracheal anesthesia excision of swelling from sub-deltoid muscle was done and examined, macroscopically and microscopically; macroscopic examination. It was $15 \mathrm{~cm} \times 20 \mathrm{~cm} \times 10 \mathrm{~cm}$ soft mass, $800 \mathrm{gm}$ weight with ill-defined and capsulated brown appearance, and cut surface show in yellow appearance of all area and with strand of fibrous tissue, microscopic examination, revealed a this fibrous capsule, fragmented fibers and mature adipose tissue and histopathological diagnosis, fibrolipoma and no malignance. The patient was followed up for one year without evidence of recurrence and the final diagnosis was submascular simple fibro lipoma.

In the 21 years military student male, presenting by swelling under left scapula after violence exercise and by examination, soft swelling lobulated and move under scapula and plain X-ray and CT done revealed no suspicious lesion and diagnosed before operation, subscapuler lipoma or subscapuler hematoma and indication of operation was pain, discomfort and ugly appearance operation done under general anesthesia and operative diagnosis was osteoma at ventral aspect of scapula articulant with 3 ribs forming false joint, surrounding by fibrous capsule with synovial fluid and specimen examined histopathology, and diagnosed, osteochondroma associated with area of angiomatus malformation and no evidence of malignance of recurrence.

\section{Conclusion}

A lipoma is a benign tumor of fat tissue. They are generally soft to touch, movable, and painless, occur just under the skin, but occasionally may be deeper. Most are less than $5 \mathrm{~cm}$ in size. Common locations include upper back, shoulders, and abdomen.

\section{Recommendations}

1- Lipoma around shoulder girdle removed under-general endotracheal anesthesia. 2Drain indicated in subscapular and giant lipoma. 3- Histopathology to confirm clinical diagnosis, 4- Lipoma benign tumor, liposarcomas not rose from lipoma. And 5- Not all physical signs found in lipoma examination

\section{References}

Bailey and Love's, 2000: Short Practice of Surgery. $23^{\text {rd }}$ ed., R.C.G. Russell, N.S. Williams, C.J.K. Bulstrode (eds). bjssjournals. Online library.wiley.com > doi > j. 1365-2168.

Dalal, KM, Antonescu, CR, Singer, S, 2008: Diagnosis and management of lipomatous tumors. J. Surg. Oncol. 97:298-313.

De Nictolis, M, Goteri, G, Campanati, G, Prat, J, 1995: Elastofibrolipoma of the mediastinum: A previously undescribed benign tumor containing abnormal elastic fibers. Amer. J. Surg. Pathol. 19, 3:364-7.

Erkiliç, S, Koçer, NE, Sivrikoz, C, 2005: Subscapular elastofibroma intermingled with adipose tissue: Variant type of elastofibroma or lipoma? Ann. Diagn. Pathol. 9, 6:327-9.

Hatano, H, Morita, T, Ogose, A, Hotta, T, Kobayashi, H, et al, 2004: Well-differentiated liposarcoma associated with benign lipoma. Anticancer Res. 24:1039-44.

Hock, R, Furusawa, T, Ueda, T, Bustin, M, 2007: HMG chromosomal proteins in development and disease. Trends Cell Biol. 17, 2:72-9.

Johnson, CN, Ha, AS, Eleanor Chen, E, Davidson, D, 2018: Lipomatous soft-tissue tumors. J. Am. Acad. Orthop. Surg. 26, 22:779-88.

Kanojia, D, Dakle, P, Mayakonda, A, Parameswaran, R, Puhaindran, ME, et al, 2019: Identification of somatic alterations in lipoma using whole exome sequencing. Sci. Rep. 9, 1:1-7.

Kanojia, D, Nagata, Y, Garg, M, Lee, DH, Sato, A, et al, 2015: Genomic landscape of liposarcoma. Oncotarget. 6:42429-44.

Loubignac, F, Bourtoul, C, Chapel, F, 2009: Myxoid liposarcoma: A rare soft-tissue tumor 
with a misleading benign appearance. World. J. Surg. Oncol. 7:42-8.

Luba, MC, Bangs, SA, Mohler, AM, Stulberg, DL, 2003: Common benign skin tumors. Amer. Fam. Physic. 67:729-38.

Malek, A, Bakhidze, E, Noske, A, Sers, C, Aigner, $\mathbf{A}$, et al, 2008: HMGA2 gene is a promising target for ovarian cancer silencing therapy.

Inter. J. Cancer 123, 2:348-56.

Nishio, J, 2011: Contributions of cytogenetics and molecular cytogenetics to the diagnosis of adipocytic tumors. J. Biomed. Biotechnol. 2011: 524067. doi: 10.1155/2011/524067.

Normal L. Browse (1997): An introduction to the symptoms and signs of surgical disease, By Norman Browse, John Black, Kevin Burnand, William Thomas, $3^{\text {rd }}$ edition.
Pallante, P, Sepe, R, Puca, F, Fusco, A, 2015: High mobility group a proteins as tumor markers. Front. Med. 2:15-9.

Suga, H, Eto, H, Inoue, K, Aoi, N, Kato, H, et al, 2009: Cellular and molecular features of lipoma tissue: comparison with normal adipose tissue. Br. J. Dermatol.161:819-25.

Ünal, B, Uzar, A, Sedele, M, Erol, B, 2015: Bilateral elastofibrolipoma: Distinguishing from elastofibroma with adipose tissue migration: $\mathrm{Ca}$ se Rep. Pathol. 2015:967670. doi: 10.1155/2015 /967670.

Zhang, M, Hu, D, Wang, S, Qin, C, 2016: Clinicopathologic significance of $H M G A 2$ expression's correlation with prognosis of esophageal squamous cell carcinoma after Ivor Lewis esophagectomy. Minerva Chir. 71, 4:239-44.

Fig. 1: Making site of incision and swelling.

\section{Explanation of figures}

Fig. 2: Closure of skin and insertion of suction drain.

Fig. 3: $5 \mathrm{~cm} \times 7 \mathrm{~cm}$ spacemen postoperative.

Fig. 4: Prone position and skin, muscle incision.

Fig. 5: A- Muscle spleting showing swelling under muscle "latissimus dorsi muscle", B- Dissection of swelling and deliver it, C-Closure of wound after insertion of drain.

Fig. 6: Macroscopic examination showing elastic, fibrous tissue with fatty tissue.

Fig. 7: Adduction of arm and elevation shoulder.

Fig. 8: Left shoulder skin incision " $Z$. incision"

Fig. 9: Spleting deltoid muscle fiber.

Fig. 10: a- Dissection - swelling from surround stricture, b- Site of swelling after dissected it.

Fig. 11: a- Closure wound in layer and remove excess skin, b- closure of skin by interrupted suture.

Fig. 12: Spacemen measured

Fig. 13: Left shoulder X-ray.

Fig. 14: Landmark scapula and site of incision

Fig. 15: A-line of incision, B- incision done.

Fig. 16: A- Dissection of swelling from chest wall, B- complete dissection of swelling.

Fig. 17: A- Articular surface at third rib covered by cartage, B- hard mass at ventral aspect of scapula caver by fibrus capsule.

Fig. 18: A- Curate articular surface of third rib, B- Excision mass from ventral aspect of scapula.

Fig. 19: A- Suturing serratus, B- Closure of skin

Fig. 20: Mass and false capsule after excision.
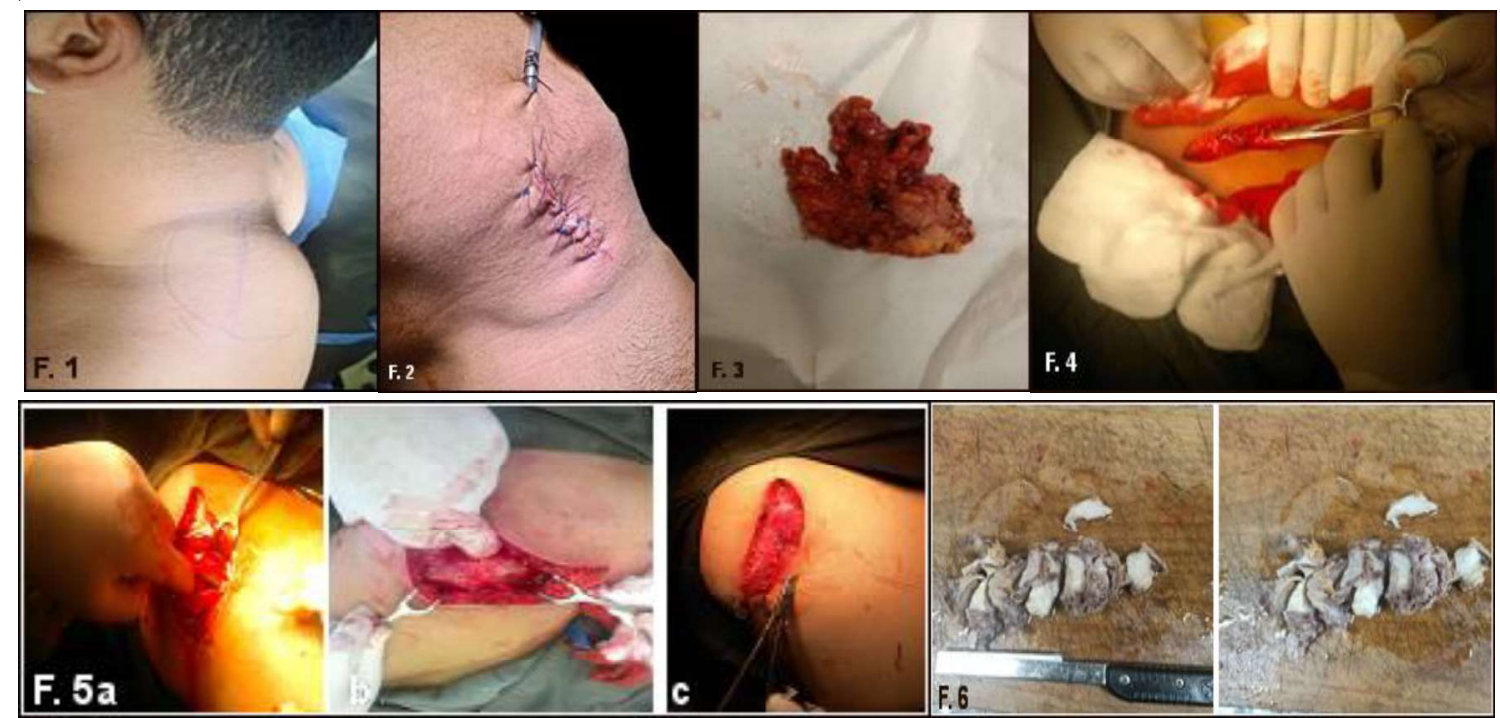




